\title{
Communication of the External and Internal Jugular Veins: A Case Report
}

\author{
Comunicación entre las Venas Yugulares Externa e Interna: Reporte de Caso \\ Rekha Lalwani; Kum Kum Rana; Srijit Das \& Riyazul Qamar Khan
}

\begin{abstract}
LALWANI, R.; RANA, K. K.; DAS, S.; KHAN R. Q. Communication of the external and internal jugular veins: A case report. Int. J. Morphol., 24(4):721-722, 2006.

SUMMARY: The external jugular vein, which traverses the sternocleidomastoid muscle superficially, is known to exhibit variations in its formation and course. There are less reports on the communication of the external and internal jugular vein. During routine cadaveric dissection, we detected an abnormal communication of the external jugular vein and the internal jugular vein, in a 45 year male cadaver. The knowledge of both normal and abnormal anatomy of the superficial veins of the neck may be important for clinicians performing catheterization and surgeons operating in the region of the neck. The presence of such anomalous communications may also be important for radiologists performing angiographic and sonographic studies.
\end{abstract}

KEY WORDS: External jugular vein; Internal jugular vein; Anatomical variations.

\section{INTRODUCTION}

The external jugular vein (EJV) which is formed by the union of posterior division of the retromandibular vein and the posterior auricular vein, begins at the angle of the mandible and descends obliquely, superficial to the sternocleidomastoid muscle, to drain into the subclavian vein. (Standring, 2005).

There are various reports on the variations of the superficial veins of the neck (Nayak, 2006; Gupta et al., 2003). The present case describes an abnormal communication of the EJV and the internal jugular vein (IJV). Usually, the EJV traverses the superficial surface of the sternocleidomastoid, to drain into the subclavian vein, but in the present case we detected another venous communicating channel from the EJV, which traversed the anterior border of the sternocleidomastoid muscle and then descended to pass deep to the sternocleidomastoid muscle, to drain into the IJV. Such a rare finding of a communicating venous channel other than the usual EJV on the superficial surface of the sternocleidomastoid muscle, may be important for surgeons who are exposed to the vagaries during any dissection. The knowledge of such anomalous communications may also be important for clinicians performing catheterization and radiologists performing angiographic studies in day to day clinical practice.

\section{CASE REPORT}

During routine dissection, we detected an anomalous venous communication on the left side of a 45 year male cadaver. The superficial veins of the neck were carefully dissected and the surrounding structures were delineated. The anomalous communication was studied in detail, appropriate measurements were taken and the specimen was photographed (Fig.1).

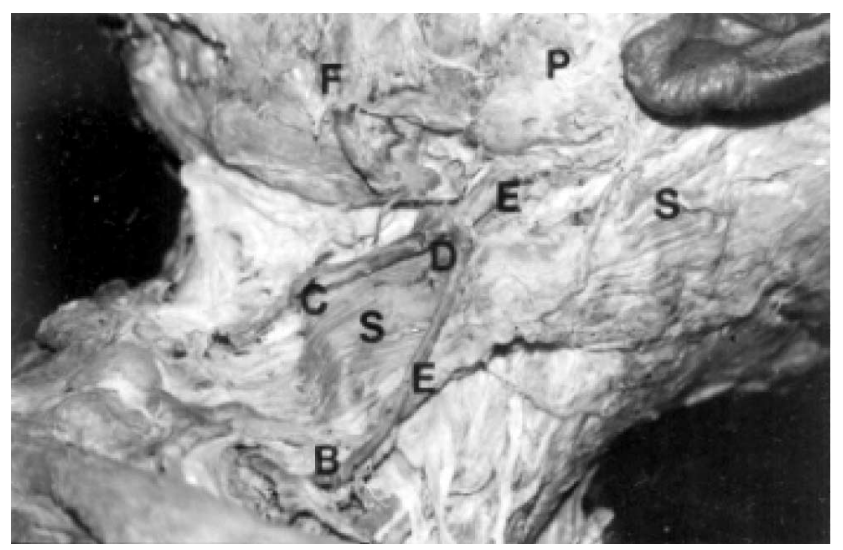

Fig. 1. Photograph of dissected specimen (left side) showing: P. Parotid gland; E. External jugular vein; F. Facial vein; O. Origin of the communicating channel from the EJV; C. Communicating venous channel; S. Sternocleidomastoid muscle; B. Dilation of the EJV before opening into subclavian vein. 
The EJV was formed as usual, by the posterior division of the retromandibular vein and the post auricular vein . The EJV descended at the angle of the mandible (E in Fig. 1). The main trunk of the EJV descended superficial to the sternocleidomastoid muscle and drained into the subclavian vein, $0.5 \mathrm{~cm}$ above the midpoint of the clavicle. A dilation (B in Fig.1) was observed before it finally drained into the subclavian vein. Another venous channel (C in Fig. 1) was observed $1 \mathrm{~cm}$ below the angle of the mandible. This venous channel arose from the EJV (D in Fig. 1), traversed the anterior border of the sternocleidomastoid muscle, to descend and empty into the IJV. The IJV drained into the subclavian vein as usual. The facial vein drained into the IJV. No abnormalities were observed on the right side.

\section{DISCUSSION}

The EJV is known to exhibit various anomalies as regarding its formation and course. Standard textbook of anatomy does mention the fact that the EJV may communicate with the IJV but such a condition is very rare. (Standring). A standard anatomy textbook mentions the fact that in one third of cases, the EJV drains into the IJV (Hollinshead, 1956). Considering the above facts the anomalous communication between the EJV and the IJV cannot be neglected.

The presence of such anomalies may be explained in terms of regression and retention of different parts of the veins as found in the monkeys (Gupta et al.). Earlier research reports have defined an accessory jugular vein in the Macaca mulatto monkeys (Al-Lami \& Poole, 1986). Thus in Macaca mulatto monkeys, one may find two superficial veins on the sternocleidomastoid muscle similar to that seen in the present case. The present case describes the abnormal communication, which may be also as a result of developmental defect.

The clinical importance of the jugular vein lies in the fact, that often the inspection, auscultation and Doppler sonographic examination of the jugular veins may give a clue for diagnosis of cardiac diseases (Baumgartner \& Bollinger, 1991). Interestingly, it is only the dilation of the veins which signifies the fact that there may be compression of the superior vena cava by any underlying pathology of mediastinum or the pericardium (Baumgartner \& Bollinger).

The jugular veins are important for any ligations which are to be performed during radical neck dissection surgeries (Wen et al., 2000). The jugular veins are often used for catheterization and prior anatomical knowledge is needed before such procedures. Color Doppler Sonography is essential for detecting collateral pathways (Conkbayir et al., 2002). In cases of variations of the superficial veins of the neck, ultrasound guided venipuncture is a possible procedure which may be performed (Gupta et al.).

The anatomical knowledge of the superficial veins of the neck are also important for neck surgeons in order to check any inadvertent injury. Awareness of such anatomical variations may be important for clinicians and radiologists performing sonographic and angiographic studies.

LALWANI, R.; RANA, K. K.; DAS, S.; KHAN R. Q. Comunicación entre las venas yugulares externa e interna. Reporte de caso. Int. J. Morphol., 24(4):721-722, 2006.

RESUMEN: La vena yugular externa, cruza transversal y superficialmente al músculo esternocleidomastoideo presentando variaciones en su curso y formación, existiendo algunos repórters en las comunicaciones entre ambas venas yugulares externa e interna. Durante ua disección de rutina, detectamos una anormal comunicación entre ambas venas, en una cadáver de sexo masculino de 45 años. El conocimiento de la anatomía normal y de las variaciones de las venas superficiales del cuello es importante en los procedimientos de cateterización tanto para clínicos como para cirujanos que operan en esta región. La presencia de estas variaciones de comunicación venosa es importante además, para imagenólogos y estudios sonográficos.

PALABRAS CLAVE: Vena yugular externa; vena jugular interna; Variación anatómica.

\section{REFERENCES}

Al-Lami, F. \& Poole, M. Venous distribution of superficial cervical region in rhesus (Macaca mulatta) monkey. Anat. Rec., 216:82-4, 1986

Baumgartner, I. \& Bollinger, A. Diagnostic importance of the jugular veins. Vasa., 20:3-9, 1991.

Conkbayir, I.; Men, S.; Yanik, B. \& Hekimoglu, B. Color Doppler sonographic finding of retrograde jugular venous flow as a sign of innominate vein occlusion. J. Clin. Ultrasound., 30:392$8,2002$.

Gupta, V.; Tuli, A.; Choudhry, R.; Agarwal, S. \& Mangal, A. Facial vein draining into external jugular vein in humans: its variations, phylogenetic retention and clinical relevance. Surg. Radiol. Anat., 25:36-41, 2003.
Hollinshead, W. H. Anatomy for surgeons. II ${ }^{\text {nd }}$ Ed. Hoeber-Harper, New York, 1956. V. 1. pp. 530-1.

Nayak, B. S. Surgically important variations of the jugular veins. Clin Anat., [Epub ahead of print], 2006.

Standring, S. Gray's Anatomy. The Anatomical Basis of Clinical Practice. $39^{\text {th }}$ ed. Elsevier Churchill Livingstone, New York, 2005. p 551.

Wen, Y.; Zhou, S. \& Wang, C. Compensation of external jugular vein to the reflux of cerebral blood after bilateral ligation of the internal jugular vein. Zhonghua Kou Qiang Yi Xue Za Zhi., 35:64-6, 2000.

Correspondence to:

Dr. Kum Kum Rana

Department of Anatomy, Maulana Azad Medical College

Bahadur Shah Zafar Marg, New Delfi-110002, INDIA

E-mail:Kumkumrana@hotmail.com

Received : 28-04-2006

Accepted: 20-09-2006 